\title{
Projecting on China-German Enlightenment and Volker Braun’s “Great Peace”
}

\author{
Hansjörg Rothe ${ }^{1,2}$ \\ ${ }^{1}$ Klinikum Coburg, Coburg, Germany \\ ${ }^{2}$ Danube University, Krems, Austria \\ Email: rothe@online.de
}

Received December $1^{\text {st }}, 2012$; revised January $2^{\text {nd }}, 2013$; accepted January $9^{\text {th }}, 2013$

\begin{abstract}
This short report outlines a work in progress which aims at highlighting the role China played in the discussions of Protestantism and early enlightenment in Germany around 1700, and how this crucial phase may be re-interpreted from the standpoint of the 1980ies, when Volker Braun's drama "Great Peace" again staged arguments illustrated with references to China. The report argues that Volker Braun's play is an important document of German-Chinese intercultural dialogue, and proposes the project of making a translated version available for the dialogue.
\end{abstract}

Keywords: Enlightenment; Protestantism; Tai Ping Tian Guo; Germany; Cultural Dialogue; Philosophy; Drama; G. W. Leibniz; C. Wolff; V. Braun

The intercultural discourse between Germany and China has become so much easier and more natural today as compared to previous centuries, that focussing on the deep misunderstandings and false presumptions underlying those old debates of the past has become a most promising endeavour: only now can we truly discover what these arguments mean, because we know so much more about each other now than our ancestors-and exactly that can teach us a lot about our past and therefore about our own cultures as they are today.

This short report outlines a work in progress which aims at highlighting the important role China played in the sometimes heated discussions of early enlightenment in Germany around 1700, and how this crucial phase may be re-interpreted from the standpoint of the 1980ies, when Volker Braun's drama "Great Peace” again staged arguments illustrated with references to China - in yet another crucial phase of German history.

The benefit of this project should be twofold: not only will a deeper understanding of this discourse shed new light on German enlightenment - the lines of thoughts, and the way they misunderstand China and refer to the "Chinese example" for the sake of making a point in inner-German conflicts, will allow Chinese scholars to better understand why the intercultural discourse between China and Germany unfolded in the way it did over the last three centuries. Not only in science, misinterpretations may give rise to important insights once their mechanisms get analyzed.

The North-Eastern German university city of Halle on the river Sala, as Shakespeare calls it, sets the stage. The constant point in space (situated in the Prussian kingdom in 1700 and in the German Democratic Republic in 1980) corresponds to the constant stream of ideas: the traditions of Protestant Christian thought and the enlightenment

\section{Protestant Bullies: The Case of Christian Wolff and His Speech on "the Practical Philosophy of the Chinese"}

Things are not always as straightforward as they seem, and
Christian Wolff's famous Prorectorate speech of 1721 at the University of Halle is one example. Although praising Confucius was an important achievement for enlightenment, Wolff's admiration for Qing dynasty emperor Kangxi (康熙), of all people, certainly wasn't. Chinese readers will be surprised to read the eulogies of the Halle philosophy professor, who viewed China through the politically biased lens of Jesuit missionaries Francois Noël and Philippe Couplet. Noël's translation of "Six classical Chinese books" served as the main reference for his speech, while Couplet's "Confucius Sinarum Philosophus" was used by Wolff for his commentaries of 1726 (Albrecht, 1985). As Matteo Ricci before them, the Jesuits of 1700 still aimed for winning power in China rather than the souls of Chinese people, and since Kangxi had granted them the unrestricted right of proselytisation in 1692 they served him as mathematicians and diplomats but certainly didn't speak out against the Qing court's shamanistic rites-which were as alien to the conquered Chinese as the Manchu queues they were forced to braid their hair into.

So being in the heartland of Protestantism, with Wittenberg and Martin Luther's birthplace (and place of death) Eisleben just a few miles away, Wolff received a full blow of Protestant bullying from Pietists August Hermann Francke and Joachim Lange, who used their influence on the Prussian "Soldier King" Friedrich Wilhelm to have Wolff ousted. But again, the motives of these two pious men were not directed against Jesuit power games (which they didn't see through), but rather against Wolff's "outrageous" suggestion to invite Chinese scholars to Halle to learn practical philosophy from them.

\section{Protestants Bullied: Volker Braun's Revolutionary Drama “Great Peace”}

Christian Wolff's teacher Gottfried Wilhelm Leibniz had been the first author to make this suggestion, as he had been the only Protestant philosopher to support the Jesuits for not critizising the pre-Christian rites performed by Chinese Catholic 
converts. His main objective had been the focus on learning practically from Chinese culture rather than discussing religious habits, and indeed up to the middle of the 18th century that was what the Europeans did: with Confucianism being the main point of interest, apart from technical achievements. In the second edition of his "Novissima Sinica" (News from China) of 1699, Leibniz included a portrait of emperor Kangxi-but he had also made the suggestion to send Protestant missionaries to China instead of leaving the field to the Jesuits.

It wouldn't be before 1807 though, that this actually happened, just seven years prior to the birth of Hong Xiuquan (洪 秀全). By that time the role of the Jesuits in China had been taken over by the British imperialists, who would soon serve the Qing emperors as generals rather than mathematicians but still intended to win power in China. The Anglican Christian C. G. Gordon, a.k.a. "Chinese Gordon" or "Gordon Pasha", crushed the armies of the Tai Ping Tian Guo (太平天国) in the name of the emperor, while Hong Xiuquan had been heavily influenced by Protestant missionary teachings and his "Great Peaceful Kingdom of Heaven” was supposed to have much in common with Luther's "Reich Gottes” (Carter, 2000).

One hundred years after Gordon's death the university city of Halle for the first time heard about the Taiping revolution, and in yet another twist of the history of ideas it was not in a public lecture at the university as the one in 1721, but in a theatre performance: Volker Braun's play “Great Peace” (Grosser Frieden) again used China as an example, this time to illustrate how far the East German Communist party rule had shifted from their original aims (Braun, 2004). His metaphors of Wang, the philosopher, and Gau Dsu, the peasant general and later emperor in the "Kingdom of Tschin", critizised the German democratic republic in the costumes of Hong Xiuquan and his followers, who cut off the Manchu queues and the whole Qing rule imposed on them since the days of Kangxi. The East German rulers didn’t like his "revolutionary drama” though, which was discussed in Protestant churches-the only places where free argument was possible, although the rulers maintained they themselves represented enlightenment. After the 1989 Great Peaceful Revolution of East Germany, Volker Braun's son-inlaw Thorsten Reich was one of the people who organized the reconstruction of the Protestant university church (Paulinerverein, 1992), which had been blown up by the communists in hisand Leibniz's-home town of Leipzig in 1968.

\section{Outlook}

- Volker Braun's play is an important document of GermanChinese intercultural dialogue, and it should be discussed much more widely by both Chinese and German scholars than it is today.

- This short report is meant to support the project of making a translated version available for the dialogue.

- Everybody who would like to contribute is most welcome.

Why not plan for a podium discussion on the subject, with Chinese and German "missionaries" learning from each other, in the year 2017-the fifth centenary of Luther's theses? Halle, the old university city of Christian Wolff, would be a good place for that to happen!

\section{REFERENCES}

Albrecht, M. (1985). Rede über die praktische Philosophie der Chinesen (p. 21). Hamburg: Christian Wolff.

Carter, R. (2000). Taiping. München: List

Braun, V. (2004). Grosser frieden. Berlin: Henschel Theater Verlag Paulinerverein (1992). Universitätskirche Leipzig-Ein Streitfall? Leipzig: Verlag Kunst und Touristik. 